УДК 9

DOI $10.21661 / \mathrm{r}-464185$

\title{
М.М. Бабаджанова
}

\section{БУДДИСТСКИЙ ПАМЯТНИК АДЖИНА-ТЕПА - СВИДЕТЕЛЬСТВО ДРЕВНЕЙШЕГО КУЛЬТУРНОГО ВЗАИМОДЕЙСТВИЯ ТАДЖИКИСТАНА И ИНДИИ}

Аннотация: статья посвящена памятнику исторического и культурного наследия Буддийского монастыря Аджина-Тепа. При проведении археологических раскопок здесь было найдено большое количество произведений скульптуры, живописи и Будда в нирване. Аджина-Тепа является свидетельством слияния в одно органическое иелое традищий и образов индийского искусства с местными, бактрийско-тохаристанскими. Этот памятник важен и в отномении выявления истоков связей и взаимодействия культур народов Центральной Азии, уходящих своими корнями в глубокую древность.

Ключевые слова: Аджина-Тепа, исторический памятник, культурный памятник, древние времена, археологические исследования, Индия, Таджикистан.

\section{Munzifakhon M. Babadjanova}

\section{BUDDHIST MONUMENT AJINA-TEPPA - THE EVIDENCE OF THE OLDEST CULTURAL INTERACTION OF TAJIKISTAN AND INDIA}

Abstract: the article is dedicated to the monument of historical and cultural heritage of the Buddhist monastery of Ajina-Teppa. When carrying out archaeological excavations, a large number of works of sculpture, painting and Buddha in nirvana were found here. Ajina-Teppa is a testament to the merging of traditions and images of Indian art into one organic whole with local, Bactrian-Toharistani ones. This monument is also important for identifying the origins of ties and interaction of cultures of the peoples of Central Asia, which are rooted in antiquity. 
Keywords: Ajina-Teppa, historical monuments, cultural monuments, ancient times, archaeological investigations, India, Tajikistan.

\section{Protection of nature, historical, cultural monuments - the duty of every}

\section{(Article 44. The Constitution of the Republic of Tajikistan)}

For centuries, India has attracted the attention of foreign scientists, historians, philosophers, linguists, specialists in various fields. Do not stay aside and representatives of science, culture, education and other areas of Tajikistan. It should be stressed that developing fruitful bilateral relations and exchanges between India and Central Asia and, in particular, Tajikistan.

We know how greatly influenced the culture of the peoples of Hindustan classical Tajik-Persian literature. On Indian soil we have evolved and thrived talents such major poets like Amir Khusraw Dehlevi Abdukadyr Bedil and whose works are included in the golden fund of both Indian and Tajik literature.

In Tajikistan, where mountain valleys bloom in gardens and forests, alpine meadows grazing huge flocks of sheep, and below, a strong network of irrigated channels bring great harvest field of cotton, rice, and many others, even subtropical crops; This fertile nature, abundance of heat and water, from ancient times attracted people. People settled here in the Lower Paleolithic - over two hundred thousand years ago. On this, as well as the subsequent development of culture in Tajikistan, clearly evidenced by archaeological finds. In the early 30-ies in the upper reaches of the Zarafshan in a castle on Mount Mug (Kalai-Moog) was found a basket of ancient documents. The expedition of the Academy of Sciences at the same time the castle unearthed was found a lot of documents, some of them managed to decipher. This discovery was the starting point for the deployment of archaeological work in Tajikistan. Shortly after the Great Patriotic War of the USSR Academy of Sciences in cooperation with the Tajik branch of the USSR Academy of Sciences and the State Hermitage Museum and organized a major multi-year archaeological expedition in Tajikistan, the head of which is one of the leading Soviet Orientalists A. Yu. Yakubovskii [5; 6]. 


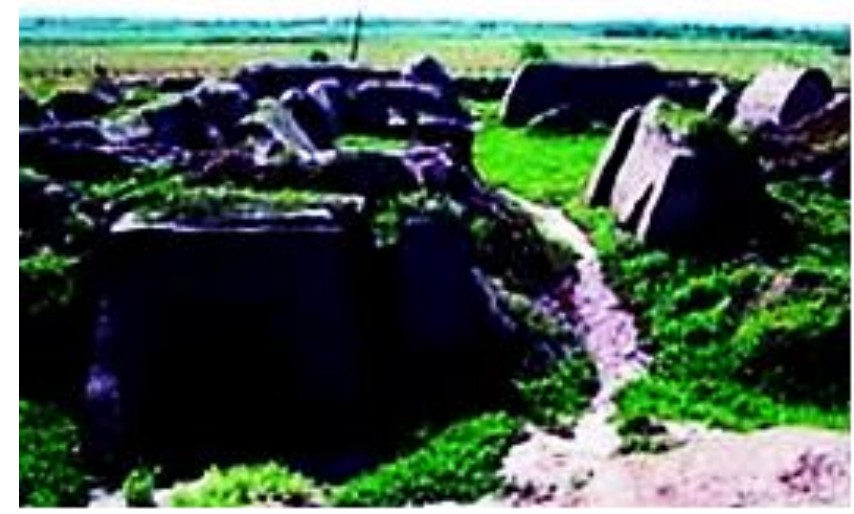

Pic. 1

In Tajikistan, about 12 kilometers east of the c city of Kurgan-Tube is AjinaTeppa - one of tt the most famous Buddhist monasteries in Central Cen Asia. It was built in the VII century BC in the valley of the Vakhsh River. This is the area south of modern Tajikistan. Vakhsh valley is located at the bottom of the Vakhsh River, one of the main tributaries of the Panj. From the west, north and east of the valley surrounded by low mountain ridges Aruk-Tau and Terekli, in the south it is washed by the Panj River (which marks the area in the state border of Tajikistan and Afghanistan).

Since 1953, the Department of Archaeology and Numismatics Institute of History, Archeology and Ethnography of the Academy of Sciences of Tajikistan under the leadership of B.A. Litvinskiy starts broad systematic study of Vakhsh valley.

«Ajina-Teppa was discovered in 1959. During the archaeological investigations the archaeologists noticed a small strangely structured mound. The first trial excavations (two digs) took place in 1960. From 1961 Ajina-Teppa became the main focus of the studies of the South Tajik archaeological department (supervisor B.A Litvinsky). It is important to note that the monastery was situated in an inhabited area, and in particular that it was not far from the Kafir irrigation channel» $[6 ; 11]$. 


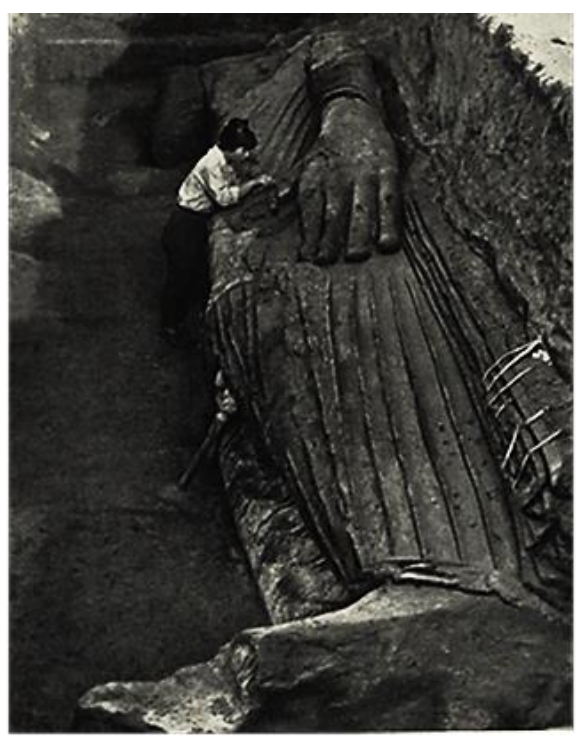

Pic. 2

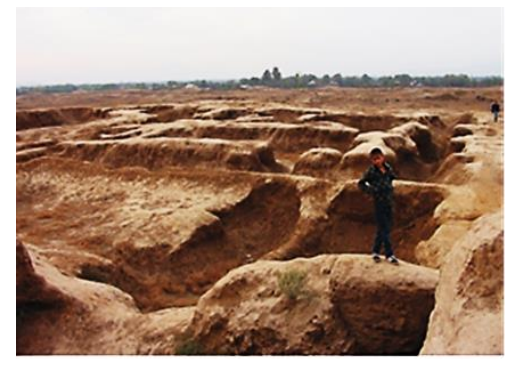

Pic. 3

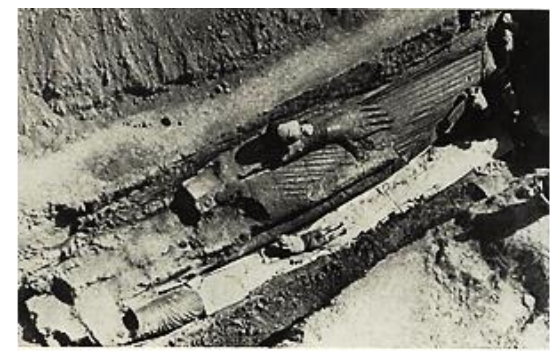

Pic. 4

Through the efforts of archaeologists discovered a whole architectural complex a Buddhist monastery VII - VIII centuries Ajina-Teppa, has dozens of religious and residential buildings. At one time they were painted with frescoes and decorated with hundreds of statues. The preserved remains of this magnificent colorful decorations (including a giant 12-meter statue of the Sleeping Buddha) to enable an even greater responsibility to identify specific communication and sheer scope of our Central 


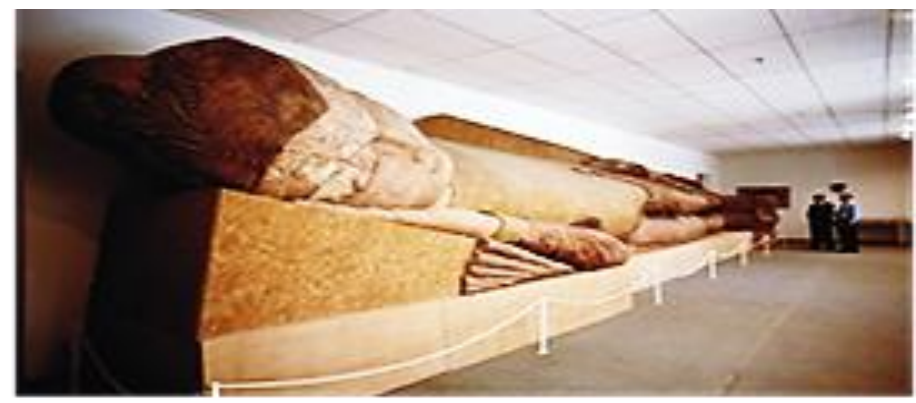

Pic. 5

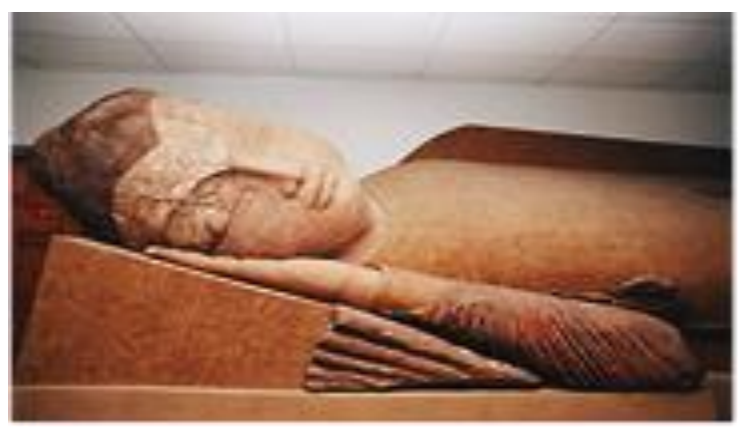

Pic. 6

Asian artistic monuments in the mainstream of Asian Buddhist art $[5 ; 6]$.

A large number of sculptures and paintings found were preserved by restorers of the State Hermitage. Primary conservation carried out on the spot. Long and complex finishing of sculpture and wall paintings of Ajina-Teppa restoration workshops held in the Hermitage [6;11].

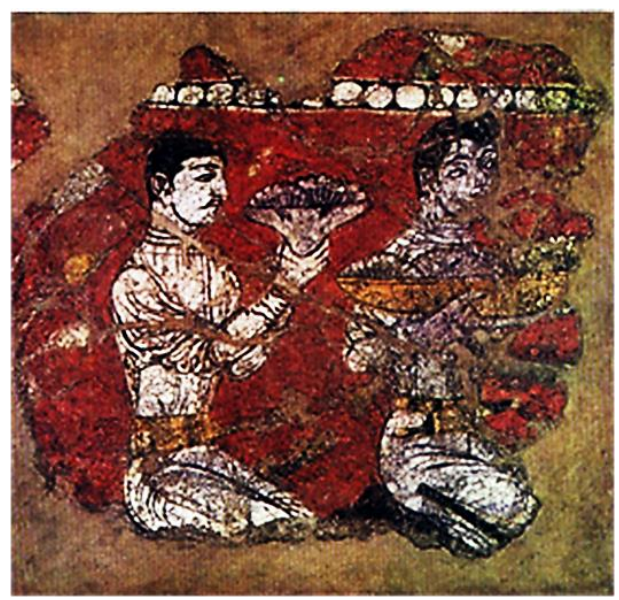

Pic. 7 


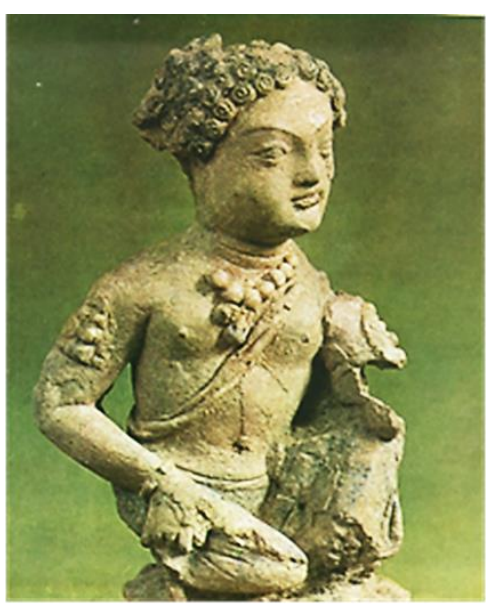

Pic. 8

It is worth mentioning that during the operation of the monastery Ajina-Teppa, in Central Asia at this time peacefully coexist different religions and cults of local and global importance. Buddhism mainly been distributed in Tokharistan, northern Khorasan and the Seven Rivers. Zoroastrianism confessed almost the entire territory of Central Asia. Christianity was represented heretical, exiled from their homeland Byzantine sects $[6 ; 10 ; 11]$.

As a result of the excavations, it was found that the building was divided into two parts which have different functions: the monastery (viharva) and the temple-sanctuary (singaharama), two rectangular courtyard surrounded by buildings and strong walls. In one of the courtyards there is a large stupa (dome for storage of relics, or to refer to sacred sites). In the corners of the court were small stupas of the same shape as the Great Stupa. The monastery was richly decorated walls and vaults are covered with paintings. Within the walls there were niches where there were large and small Buddha sculpture (its image in general occupied a central place in the sculpture Ajina-Teppe).

In the corner the northeast corridor on a high pedestal was found reclining figure sculpture «Buddha in Nirvana» in the traditional pose of a sleeping lion.

«The temple section of the monastery was decorated with many painted sculptures made of clay portraying characters from the Buddhist pantheon. During the excavations a head of Buddha (1/3 natural size), heads of bodhisattvas, heads with black and blue hair, and heads of different deities and monks were discovered. There were lots of 
sculptures: the body of the warrior Mar, representations of nobles, supplicants, demonic creatures and monsters. Among them there are many original and unique masterpieces of Central Asian Buddhist art» [11; 14].

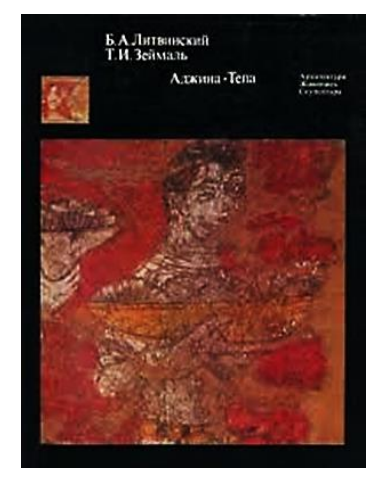

Pic. 9

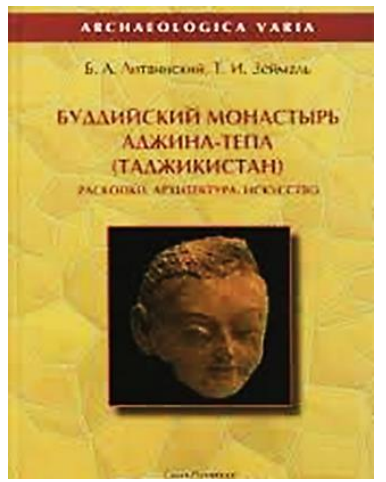

Pic. 10

B.A. Litvinsky described the sacred Buddhist ceremony, which was held in the convent Ajina-Teppa. The solemn procession of Buddhist pilgrims gathered in the courtyard of the temple half "... where I stood a powerful array of stupas. With four sides half-pace stair railing with a steep climb up to the foot of the hemisphere. And if you raise your eyes above, you can see seven umbrellas top stupa. The monks and the faithful laity committed ritual circumambulation around the stupa and various donations. Stupa, the most sacred part of the monastery, so she decorated differently... After the ceremony Pradakshina, bypassing the process takes space fence... The rooms were poorly lit. Narrow shafts of light penetrating from the openings, scattered, the upper $\Gamma$ shaped corridor, as well as their walls, were buried in the shadows. Groups of worshipers were carrying lamps, lots of lamps, and fluctuating flames created a whimsical illumination, snatching from the depth of detail of paintings that covered the walls from top to bottom corridors. It was a large medallion with the image of Buddha; they were 
surrounded by other, smaller images. And on the opposite wall of the courtyard, we have passed the history of the spiritual life of the Buddha, but not in the form of consecutive pictures, and like a string of individual frames - is seated Buddha sculptures in the niches» $[5$, p. 134].

Archaeological excavations have helped to remove from the earth more than five hundred works of art: sculptures, reliefs, fragments of wall paintings left by an ensemble of residential and religious buildings Buddhist monastery VII-VIII centuries, which led to the surprise of everyone. Great contribution to the archeological excavations, scientific research and study, preservation of the Buddhist monastery Ajina-Teppa played and play scientists of the Institute of History, Archeology and Ethnography named after Akhmady Donish Academy of Sciences of the Republic of Tajikistan.

The monastery, built in the XII century, operated until the VIII century. Its final destruction and desolation associated with the consequences of the Arab invasion. The monastery is actually operated for about 100 years.

In 2000, after the completion of the National Museum of Antiquities of Tajikistan sculpture «Buddha in Nirvana» was mounted.

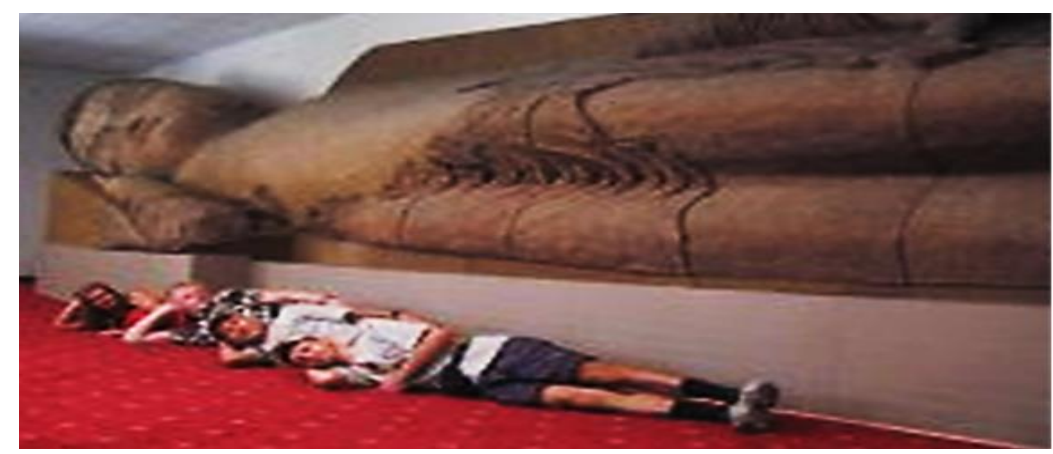

Pic. 11

In November 2004, the Institute of History, Archeology and Ethnography named after A. Donish Academy of Sciences of the Republic of Tajikistan held a trilateral meeting - UNESCO official representatives of the government of Tajikistan and Japan, with the participation of international and national experts, which was approved by the Action Plan for the Conservation of Historical and Cultural Heritage Buddhist monastery Ajina-Teppa. In May 2005, UNESCO Headquarters in Paris before the opening of 
the Festival on Cultural Diversity and Dialogue in Central Asia, an agreement was signed between the Government of the Republic of Tajikistan and UNESCO for the preservation of monuments of historical and cultural heritage of Buddhist monasteries Ajina-Teppa (VII - VIII c. BC) [2, p. 59-60].

In the course of excavations at Ajina-Teppa was found a large number of works of sculpture and painting. According to its artistic merits artwork Ajina-Teppa not stand in isolation: they are the embodiment of the ancient artistic talent Toharistan Bactrian successors.

In 2004 a UNESCO mission visited Dushanbe - Japan trust fund conservation of World Cultural Heritage with the aim of the project for the conservation of Buddhist monasteries Ajina-Teppa. The National Commission of the Republic of Tajikistan for UNESCO held a meeting of the International Scientific Committee of the control (Steering Committee) with the participation of officials from the Government of Tajikistan and Japan, embassies and international organizations accredited in Tajikistan, as well as international and national experts [2, p. 59-61].

In 2006-2007, the work on the excavation Ajina-Teppa continued. The participants were foreign and local experts under the supervision of the Japan Center for International Cooperation in the field of preservation of the National Institute of Cultural Property (Tokyo) Kazuya Yamauchi. There have been partially removed debris and sagging walls, niches and conserved unstable wall.

Within the framework of the UNESCO project «Preservation of the Buddhist Monastery Ajina-Teppa in Tajikistan: the legacy of the Silk Road», which was carried out by the Japan Trust Fund with the assistance of staff of the National Museum of Antiquities of Tajikistan, it was partially cleared the area around the monastery, taken archaeological dumps from Southwest, South and South-Eastern part of the monument, archaeological pits laid to delineate the outer side wall of the monument.

Buddhist monastery Ajina-Teppa is not an example of «transformation» and merges into one organic whole tradition and images of Indian art with local, Bactrian and Tokharistan. That is what gives the unique beauty of the sculptures Ajina-Tepa, 
and that is why Ajina-Teppa (along with Fundukistanom) is one of the most remarkable monuments of early medieval art of the East.

In January 2008 in New Delhi held the International scientific conference devoted to the Great Silk Road, which brought together more than 50 countries. Embassy of the Republic of Tajikistan in the Republic of India (during this period I worked as an Counselor of Political Affairs of the Embassy of the Republic of Tajikistan in India) has prepared an exhibition timed this conference. Our exhibition was visited by the Minister of Foreign Affairs, H.E. Mr. Mukherjee - the current President of India. In the process of exploring the exhibits, H.E. Mr. Mukherjee I was presented the book «Kaleidoscope of Cultures», in particular, his attention was drawn to the material tells about Ajina-Teppa [2, p. 59-61]. H.E. Mr. Mukherjee was genuinely interested in the fact that Tajikistan is Buddha in Nirvana. At the request of the Ministry of Foreign Affairs of India, I gave this edition to H.E. Mr. Mukherjee. Now H.E. Mr. Mukherjee is the President of the Republic of India.

Ajina-Teppa - Buddhist monastery of the XII century important in another respect - with respect to identifying sources of communication and interaction of cultures of the peoples of Central Asia and India, rooted in antiquity. In the era of ancient and medieval Central Asia and Northern India for many centuries, about more than half a millennium was part of the same public entities $[5 ; 6 ; 2$, p. 59-61].

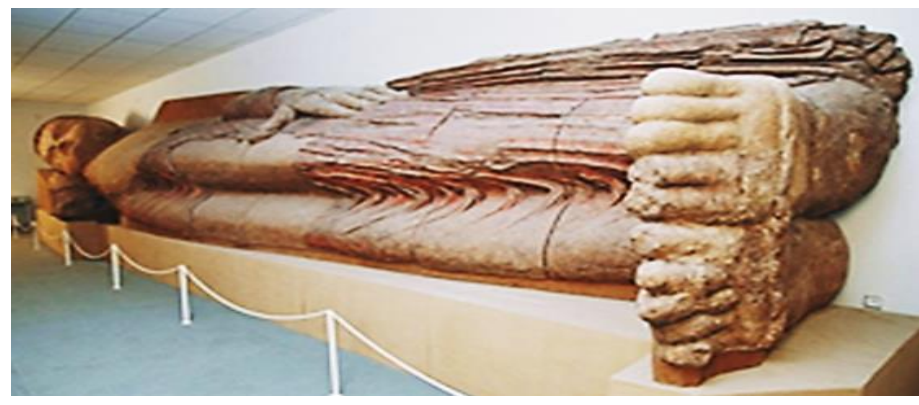

Pic. 12

Therefore, the lines of ethnic, political, military, economic, religious and cultural ties... and contacts since ancient times unite the peoples of Central Asia and the Indian subcontinent. These connections were two-sided; they fertilized the culture of friendly nations. The great scientist Abureyhan Biruni wrote a remarkable work - «The book contains an explanation of the Indians belonging to the teachings acceptable reason or 
rejected» (abbreviated «India»). The largest Russian orientalist V.R. Rosen characterized the work of al-Biruni said: «This is - a monument to one of a kind, and it has no equal in the whole of ancient and medieval literature of East and West». Treated with the greatest respect to India, al-Biruni gave a broad picture of Indian science, culture, religion. Materials collected in the XI century Central the history of this country [5, 67].

Academician B. A. Litvinsky in his edition of «Ajina-Tepa. Architecture. Painting. Sculpture» wrote that «the discovery and study by scientists of the Academy of Sciences of the Tajik SSR monument Ajina-Teppa not only recreate the important pages of the history of culture of Tajikistan, but also serve the noble cause of the further strengthening of friendship and cooperation between peoples» $[5,7]$.

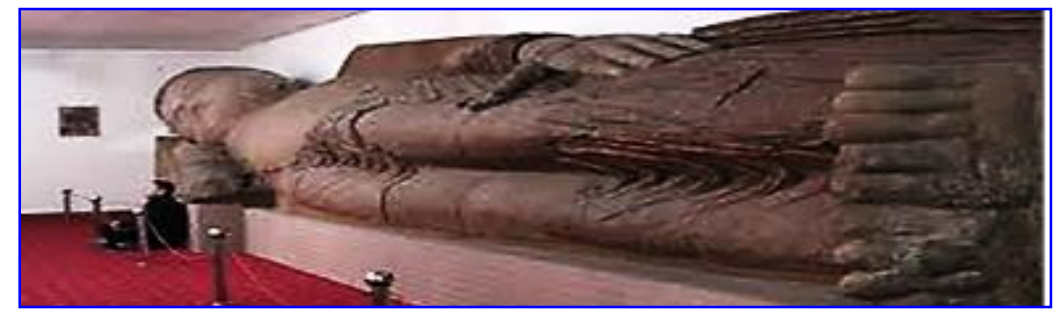

Pic. 13

After the destruction of Buddhist monuments in Afghanistan sculpture «Buddha in Nirvana» from the convent Ajina-Teppa remains one of the most famous and colorful relics of the world culture.

\section{References}

1. Babadjanova M.M. Buddhist monastery «Ajina Teppa» - for future generations. Diplomacy of Tajikistan. Ministry of Foreign Affairs. - 2006. - №16. - P.146147.

2. Babadjanova M.M., Yuldasheva M.R., Kim B. Kaleidoscope of cultures / Edited by M.M. Babajanova. - Dushanbe: «Status», 2007. - 95 p.

3. Hemang Desai. The Buddhist Treasures of Gujarat. - Gujarat, 2010. - 109 p.

4. Khmelnitsky S. Between meals and the Arabs: the architecture of Central Asia V-VIII centuries. - Berlin-Riga: «Gamajun», 2000. - P. 217-220.

5. Litvinsky B.A. Outline History of Buddhism in Central Asia. - Moscow, 1968. - 127 p. 
6. Litvinsky B.A., Zeymal T.I. Ajina-Teppa Architecture. Painting. Sculpture / Institute of History named after Akhmad Donish Academy of Sciences of the Tajik SSR. - M.: Art, 1971. - 260 p.

7. Litvinsky B.A., Zeymal T.I. Excavation and exploration in southern Tajikistan in 1961 // Archaeological work in Tajikistan: A Collection. - Dushanbe, 1964.Vol. 9. -187 p.

8. Litvinsky B.A., Terentiev-Katansky A.P. History study. Travels. Expedition. Archaeological excavations // East Turkestan in antiquity and the early Middle Ages. Sketches of history. - M., 1988. - Vol. I. - 126 p.

9. Novikova L.P. Problems of restoration of the Buddha in Nirvana // Material Culture of Tajikistan. - Dushanbe, 1978. - Vol. 3. - P. 86-92.

10. Taddei M. A Note on the Parinirvana Buddha at Tapa Sardar (Ghazni, Afghanistan) // South Asian Archaeology, 1973. - Leiden, 1974. - P. 64- 73.

11. The sleeping Buddha and the carved tympanum of Ustruchan. // ACTED Cultural Center «Bactria». - Istanbul: «Mega», 2004. - 32 p.

Бабаджанова Мунзифахон Мирзоевна - канд. ист. наук, доцент, заведующая кафедрой культурологии, директор Информационно-ресурсного центра $\mathrm{OOH}$, заведующая кафедрой ЮНЕСКО «Межкультурный диалог в современном мире» МОУ ВПО «Российско-Таджикский (славянский) университет», Республика Таджикистан, Душанбе.

Babadjanova Munzifakhon Mirzoevna - candidate of historical sciences, associated professor, head of the Cultural Studies Department, director of Resource Information Centre of UN, head of UNESCO Chair «Intercultural Dialogue in Modern World», Russian-Tajik (Slavonic) University, Republic of Tajikistan, Dushanbe. 